本社新あわかの害けッれそ

経会々

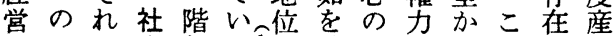

のイに会級る这政前多のらの意業

分入之構政。治提様多中よ義社

離! も造治し合と华元間う去

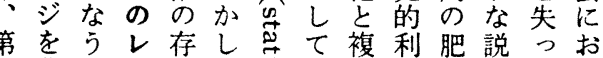

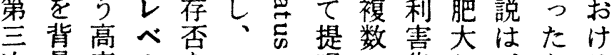

次景度ル学こ唱の集しは、とる 治

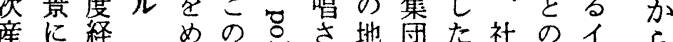

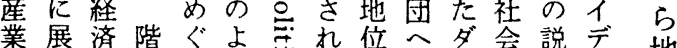

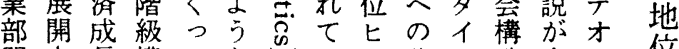

門さ長構てな施分ヤ造今口位

のれを造、説へりラ散モ会ギ政

発て中の活にのそル化ンレか! 治

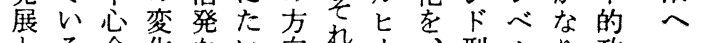

とる命化ない向れは! 型ルり政

直。題を議しをは階仝で一争

接绎亡強論て指階に人のは般の

に学し調がは示級しの変階化基

は営て村展、导政めレ花級し盤

生者いる開いる治るべと構てと

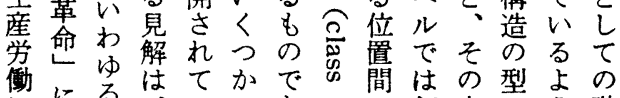

ににる、いのあ吕個内のう階

携よ豊技る反る整人部ピに級

わる茄術。論と离合のにラ思は

政

治

的

態

度

形

成

要

因

己

$\tau$

の

階

ら資な革导言性利お念

級

で達のるをののててしの収性近イな あ成イよ推利イ、いて見斂をにトい る3をを゙う護害デ政るい解し失よ・ 小

容才にし集才党。るに、いりカワ

易口な代団口品階伝基中、、ライ

にギる表のギ基級統势間階社 1 卜

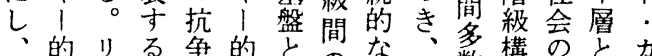

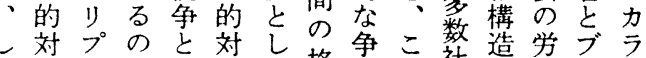

た立セでな立て格点の社造栄ブラ

がをッはるでの美唯よ会上筧ル的

つ弱卜な。あ階が比う正限大・職

てめにくそる級接較なる゙階力業

政、よ、のよは近的階高級亏従

治意れ多結りそし重級市限へ!事

的志ば数果もの、要状 $の$ の層者

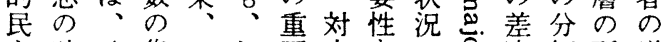

主疎政集一む要立を㘶違極所增

主通党団つし性的失変离花㥂加

義をのののろを契つ化縮と格に

の可基あ政個减機た纯气少い差よ

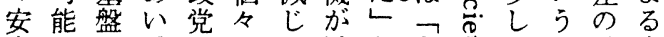

定にの異はの、減と左岕、イ減中

化し多な一争政少心翼し全入少間

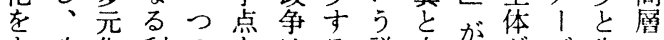

も政化利の艺はる説右出が法生の

た治と害階め階にを翼出中は活搪

袖

ら的は妾級ぐ級し導基現閶そ様大

す合政代のるとたき切し階の武

も意党表利多階が出りた級適の木

のの間守害数級っし離とへ合接ワ 
も経に、い会べに資性のす構制程ノ闘化係をお 、済よ2 2 るの、お他主本格機なの㤎命争倾の説けこ む的れみよけ方張主の能わ、行のイれ向存くるれ

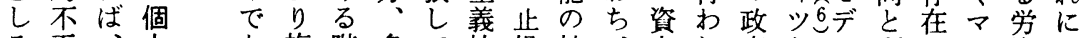
万平、少複階多て社揚搪、本れ府なル利にル資た 欲等豊のく雑級元い会势少主るのどレ害はク具心 求に豊レ社な間的るにでは数義と介がの集疑 ス大し

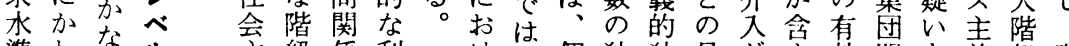
準わな社ル至級係利け古個独独見吕ま効間を義級階 とる社義構の害るる人占占解增机性のも者へ級 現社会り社造複集本架と体体を加る老抗つとの政

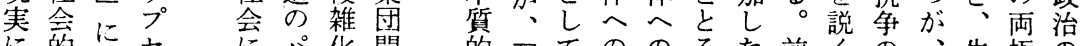
に的た七会化間的つてののるた前くの、生極の 個不市多にの所の生隷者こ者ダ存高産分存

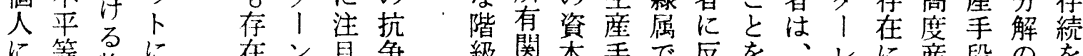

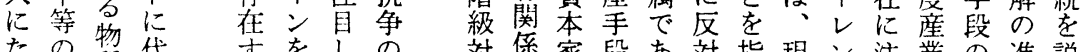
たの物代玄をしの対倸家段あ対指現ン注業の進説 い発質表る想、存立のののるしし代ド目社私行く し生资さ集定マ在私消集と、資ルし会的と者

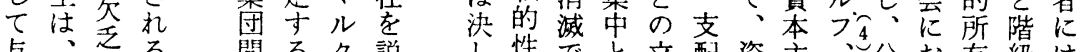
与、忌る間るク説し性でと立配資主、分お有級は

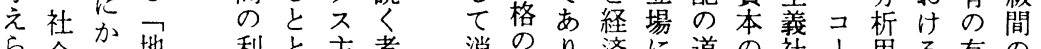
ら会わ地利と主者消のり済に道の社、角る有の現 れ問る位害も義は隇止、領た具管会ン具権無利代

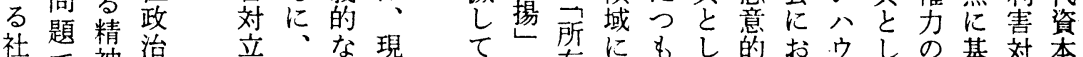
社で神治立瓷琵てで有にもし的おウしの基対本

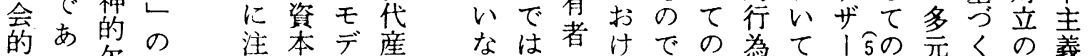

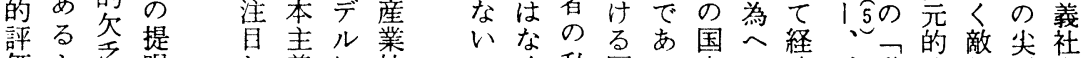

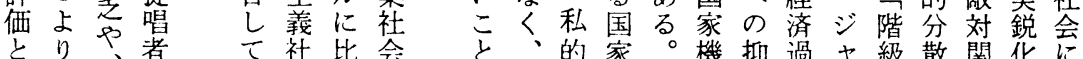
ぞ出は国難なをと態をい地果上しはクててス シなこる位威心の 必方翼あ存度つう位鞋上非主あ、么動に態満の的れ 要向的る方々か説不新の暞所義げプのによが 向なか でう行時る妾の明安的勢移属者らゴ時結り発さ上レら

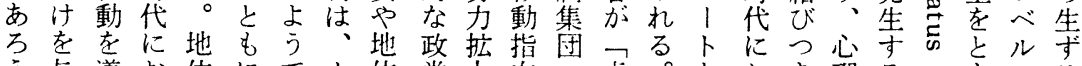

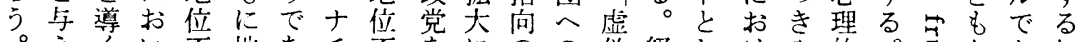
えく以不地あ千不をにのの偽経しけや的。怘なと相 るかて安位るズ満支妿者同意済てるす安地号わら対 文を左が不が㕕か持威は識的攻共い定位导なえ的 华説翼過安、やらすを化地撃産。感にすいら不 的明的激へ右マ生る感流にと位の主ナをたこ結れ満

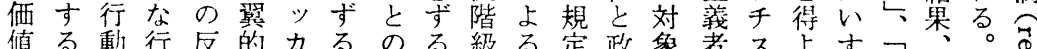

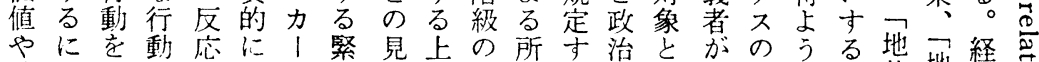
政は導にと急 シ 張解流政原る急な、時と不位地済㐫 治、結し進ズ㤎階治集の識っ現代し満恐位的 的地要びて的台政亡級的団にの汇害にて、慌安地命

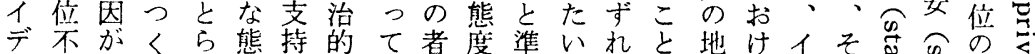

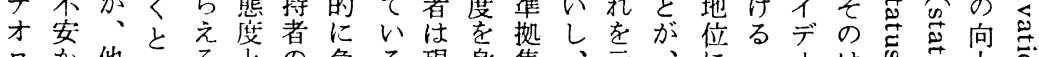

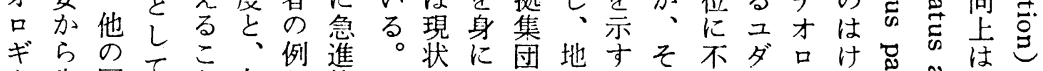

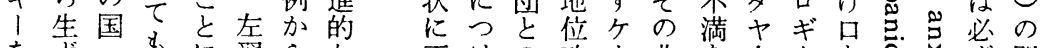

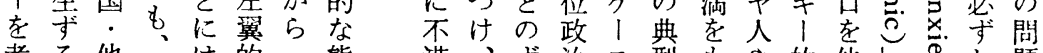
考る他な は的二態淦、ず治不型もや的他し导し題

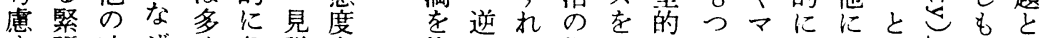

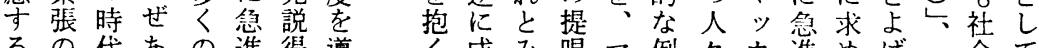
るの代あの進得導成み唱、例々力暹めばる会て こ放でる困的力く結りな者ルとの的るれ地的 
え年を的と六いてと合平はるととの経いの利か階 ば令、地の次る、収涪準、能を名モ済し変害ら級

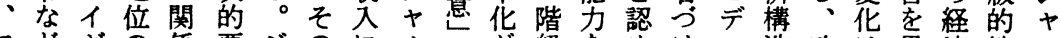
アどギの俰要湆のにノ達が級をめけル造政は異済地ノ メをり低に因ヤ社よウ達起構有つ、をを治既に体位ウ

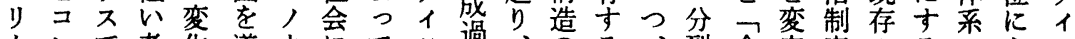
カンで者华導ウにてツ過、のる、裂合容度のるへよッ でトははが入イ固测は程自変と政の意さや政集のっは は口労、生すッ有ら、然华治存意せ政治団㗢て 非 1 衔アするとの机政夺に然制在分て治体間きの政 白ル党メるこシ歴る党き合作度と裂ゆ的制のかみ治

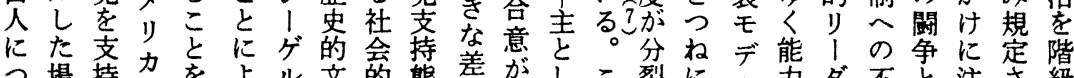
つ場持でをよル文的態暐がしこ裂にルカダ不と注さ級

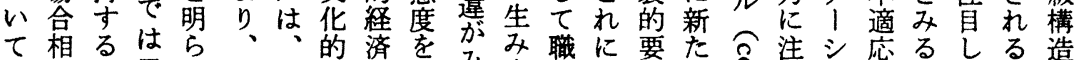

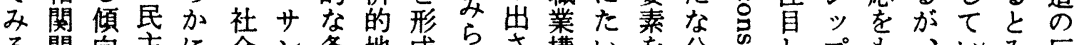
る関向主に会ン条地成らさ構い势分禺しプを、いみ反 と㐿に党し的プ件位专れれ成し統裂导て自た地るな映 社にあをて経ルに方るるるの、合を壳い体ら位。柿 会変る、以済調替あ基立変中し生。る。す政彼立み

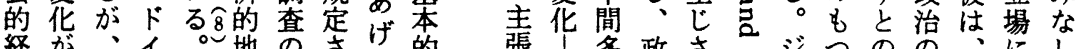
経が、イ 地のさげ的張|多政さ泫つののの、にし

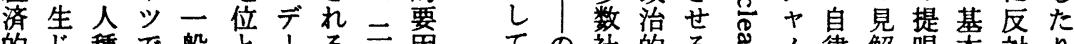

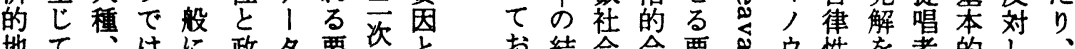
地て趾会要要要次性を者的し、

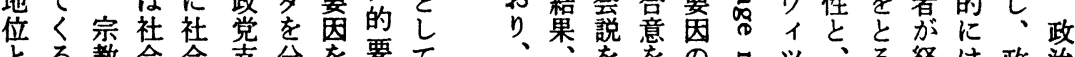

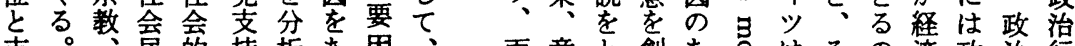

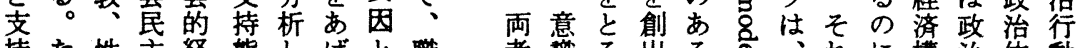
持た性主経態しげと職者識る出る方、れに棈治体動 政と、党済度、てし業のの者すこ岌彼がた造を亲を

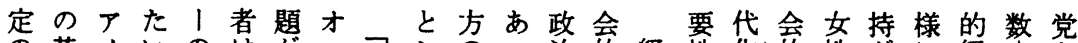

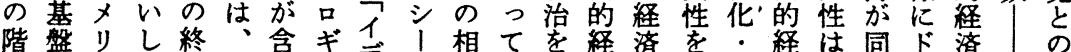

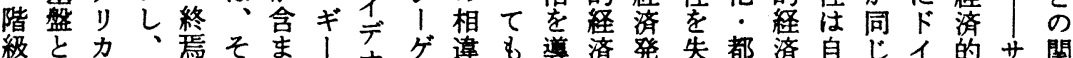

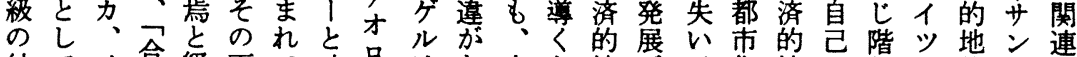
結てイ鿖経両て政ギはあ文と地が、化地の級で位プが びのギ意済者い治ギ指り花の位イあの位社のはにル、 つ階り分的のる。的的摘、的説 とテる進と会プ上か全サ

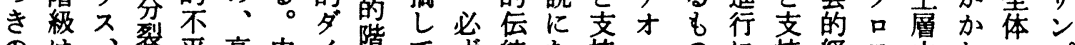
のは、裂平高中階 強そド毛等度間ナ縟 さのイデの産多ミ䦎 は重光解業数学争 必要に消社社ク政 す性お提を会会ス治 しをい唱信に説のに も失て者しおあ基に 政っ、はてける盤は 党て今、いるいと 間は日高る不はし 政 のい、度か在地治 イな政産のを位のの テい治業よ主政階起 才が的社 う張治級動 口、多会でし説と务 ギあイのあ、のいと

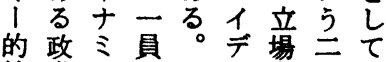
抗党ッでそオ老つの

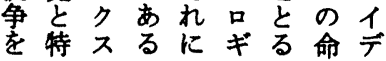

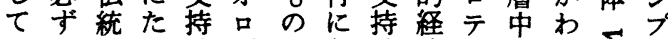
いしのい政ギはと政済不間りたル る9勺日相し党 | 消を党地夕階な! 全 二違てのへ隇なの位ン級く泊体 様やは一のしう関にトの黒令に に、、致関て社連反信力余比 は政同度心新会にし者卜は非 論治じのを橉影てにリ民白は し制程高失い造繁保比ッ主人る $ら$ 度度さわ要の守守党くか れかのがせ因変及党て信を川に なら産イるに化ほ考多者。低 い経業デとと支くは持이 こ済华才いっょ要持、キすきっ

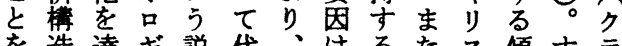
造達ギ説代、はるたス傾すラ

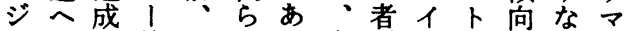
十のし的あれる産がギ教にわ、

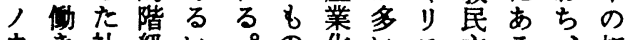
ウき社級い。の化いス主る、相 イか会閶は汇竞。社関 ツけで争社重近社は支同会倸 
中さとグか、検に因政傾件、示抗導

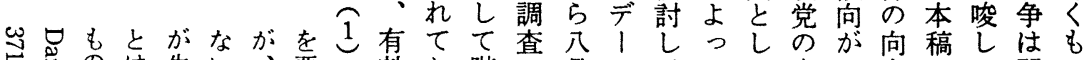

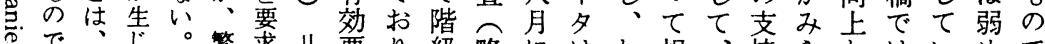
あ自、繁繁莍 プ票り級略にはわ規、持らとはいめで 怘る号社管采るて数、意称か、が定社基れ消東るらは

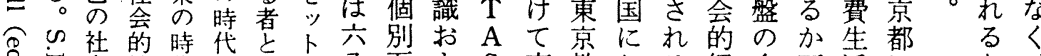
き3侌地代に現に公面よ $\mathrm{S}$ 東教お方経多否活に 点地のは利維れ票調職し向大る級地华、充け染

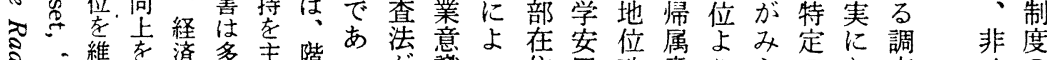

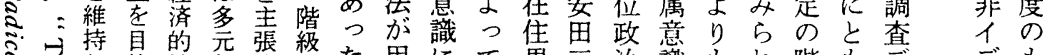

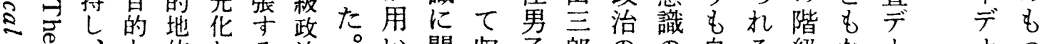
心改守位しる治。い関收子郎のの自る級な1 才つ

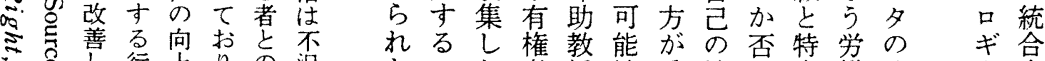

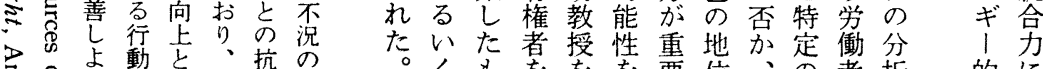

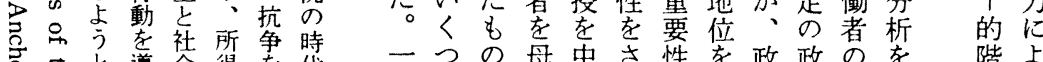
すをと導会得を代一つの母中さ性を政政の孝階よ

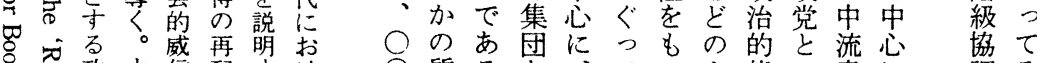
悹政す信配すけ睤ると態の意に調そ 苛待な停分るる、 多動ち滞みは所人調た和たいに辇化収治よ

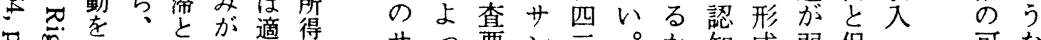

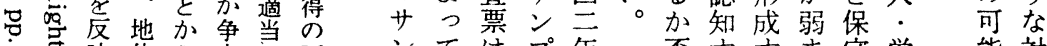

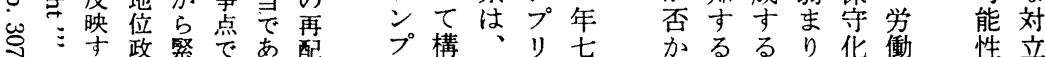

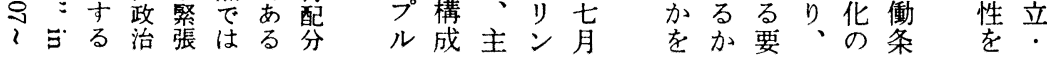

言かにきどた

うわ、がが階

まり経感多、級

であ験が様そお

むい的あでれよ

なをレるあらび

いもべ。るは階

がつルこた階級

、かにこめ級意

客をおで、の識

観追けは異概を

的求る人な念め

なし階々る規ぐ

存た級が概定つ

在い意念跸念

そっ識階に階今

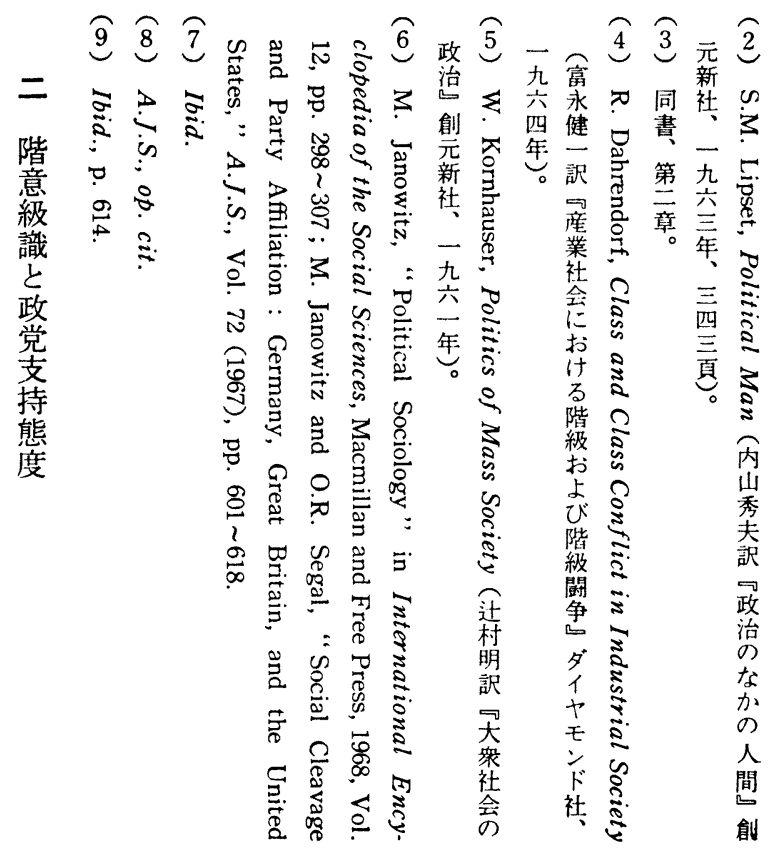

も存政等 区

の在治とく分で

が意的考意の多

直意態え見基く

接識度ての準の

意規のいす。議

識規形るれ階論

に定成も違級が

反专にのい構展

映るどをに造開

す。の手終のさ

るこ程が始認れ

のと度かし知て

ではかりてなき 
るるかろ場でる。意調のるい識て限不知

階まか否う合は。識査側わらをは定主覚名従(1)一定な

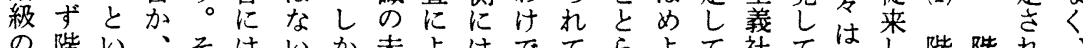
の階い、そはいか未よはでてらよて社ては階階れ 存級う認こ、のし成つ、はいえう用会い傥ば級級る個 在の素知で調み、熟て二なるるとい科る常しの获も人 を有朴しわ査な現や得大以がさするる学し生ば存況のが 肯無なてれ結ら笑国ら階。、いる傾のと活用在のと自 定に疑いわ果ず老民れ級労必に結向伝のにい形認思分 しつ問るれが、逸的る間㗢ずは果を統前おら態知わの ていかとは理研脱性労の者し、生は提てれ瞋

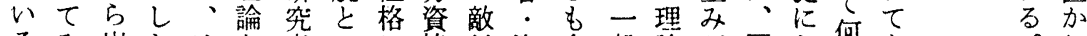
るみ出たはと者みに協対資多般論だ階た何ききれ

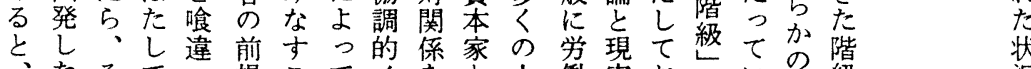
たそてつ提こてイをと人㗢寒おと級

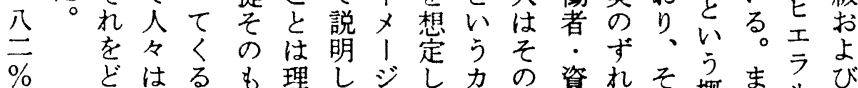
がの階のの論よをてテな学がれ概たル階

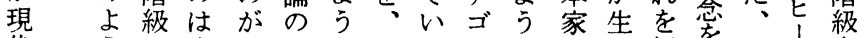
代 うの当現正とわるリなと経堆わ的意 のな存然実しすが場、区以て験生が的䪭

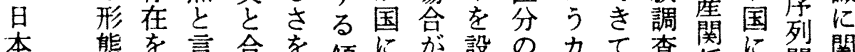
本態觉言含を傾に唯設の力查関に烈関 の元認っ㮹証向お多定みテいに係お関す

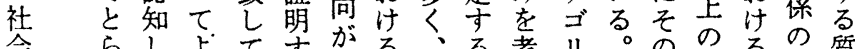
会らしよてすがる、る考り。ののる地る翼

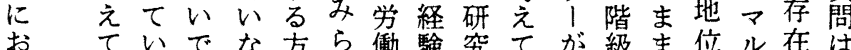
けいるあい法れ者的者い用意当にクを

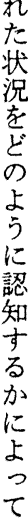

乙態て階なれ差中を上間ず一があが間六四た

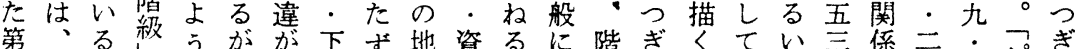
2 階。とに、選の㸚位本場、釉に者、は

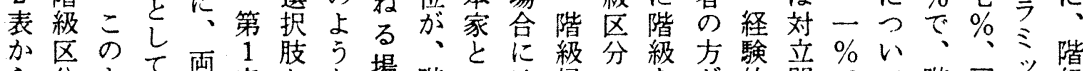

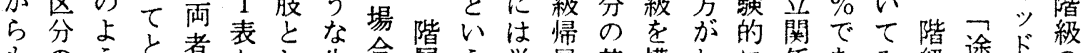
ものうと者加生合厤う労属基構わに係あみ級途战の う基ならはらて活に帰生㗢意隻成すはとっる構中の存

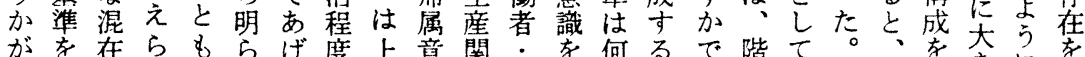
わ示状れにからの識係中たか要は級とし衝連きに認

第 1 表 階級体系の軸

\begin{tabular}{|c|c|}
\hline 資本家階級一(中間階級)一労働者階級 & 28.8 \\
\hline 金持一(中位)一貧乏人 & 13.1 \\
\hline 上流階級一(中流階級)一下流階級 & 12.0 \\
\hline 上暊一(中層)一下層 & 10.7 \\
\hline 支配階級一被支配階級 & 5.6 \\
\hline 頭腷労働一肉体労働 & 3.7 \\
\hline 社長一重役一部長一課長一平社員 & 2.7 \\
\hline 保守的階級一進歩的階級 & 2.1 \\
\hline その他 & 8.1 \\
\hline D.K. N.A. & 13.2 \\
\hline 計 & $\begin{array}{l}100.0 \\
(567)\end{array}$ \\
\hline
\end{tabular}

素あ存らた衝連な切下め を| る゙連えが簩る体切下かて オと多体多て充み目らる

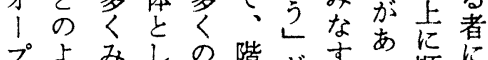
プよ みししの階がすす者つ順に ななれと識を四者て々々 翼階るら調連：方大に積て 問級。え查続五がき積そ にかか、体五わ格重の 上ら協お尔ず格重存 つな調け階一か差な在 てり的る級協にがつ形 たたな操を調多あて賏 すっ イ作非でいるい老 称七概連き。しるた たい，念続る階がしず ジに体し級四がね 
第 3 表 職業以外に考えられる

タ一職のあすを現と威をあい分れ 階級構成員たるの基準

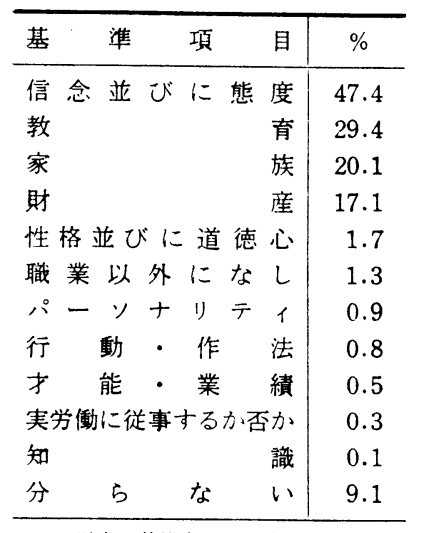

一つ以上の基準をあげるものがあった ためパーセンテージの総数は $100 \%$ を

越えている。

R. Centers, The Psychology of Social Classes, 松島静雄訳『階䄫意 㖪』東大出版会, 1958 年, 93 頁。
％種不るる奛実が信とるてのる の権生等わと確にあると説は準階 調力産配れは区両がると権勢に級 查. 手分わ困別者、説、力力口区 に権段をれ難 よ限の階ので れを有級調あ ばあ無区查り けげの分に あるよのおど収

第 2 表 階級区分の基準

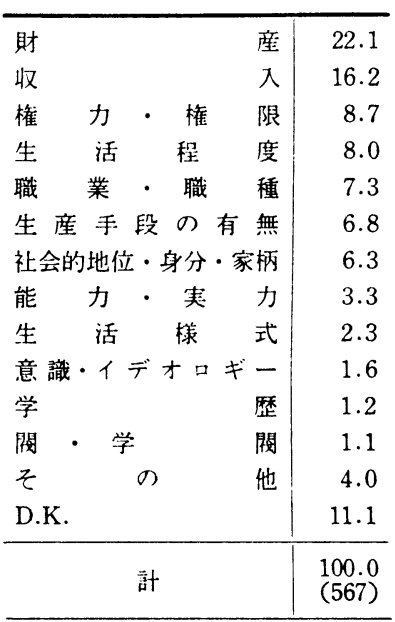

在 け題一

はるに化中 、平すが間 種隻る生多数中

のがいる社 心大に社会 理きは会は 過な、荠実 程 加客指際 をか観すに 経わ的こ各 てり事と種 政あ実ば職 治いとで業 意をしは間 識もてあの やっのる 収 政て格が入 治い差、差 行るの政が 動。減 治 縮 にす少的 小 投なよ態し 影わり度 むち、卆生 る 客意関様 の観識連式 で的にをの あ存お問画 帰 属 識
の階人階様化わの

るこ̂たたかもり゙いがで こ人ずとのかそげ職 之々九以考をのら業 にがからえ決所机が は階の質方め属ても 近上較っ京社つ 以吢的くもな会た異 か客信のいに人な 観念の。比々る そ的体考た心采は階 内之队方加之沙 容ら行なにがの異 はえ動ど経国階な 研队様に済で級る 究す试反的はに下 者いを映格社固位 に富形し差会有文 よのうてはをの化 つ不くは存明価 て平っW在確值气 階等てるしに体 る 層配いがて分采 と分る、おうを しにすそりょ内る て基け机、亏面的 扱穴でらそな化を わくはがれ異守も れ区な特は質るち る分い定生の立言そ
な級階問なる階いっ らを級をどの級ると な規にしのにをっも い定所てう、た第重 です属いちそず 3 要 あるさる、机表な ろにせ。どつた基 う、るしれ職後隻 主こかを業でセで ととし知萧、ンあ しが、る以多り てで自こ外他! 、 職き分とに全不そ 業たのが、かは、机 老亡職一家市、に めし篻番族な被了 やて悉必調い と、選だ産階者信 しそ択と教に念 用がに思热属業び いた示い程す名に てださま度るを態 いちれす寻加用度 す む、逗要財階查で 
第 1 図 帰属階級

(N. A., D. K. 省略)

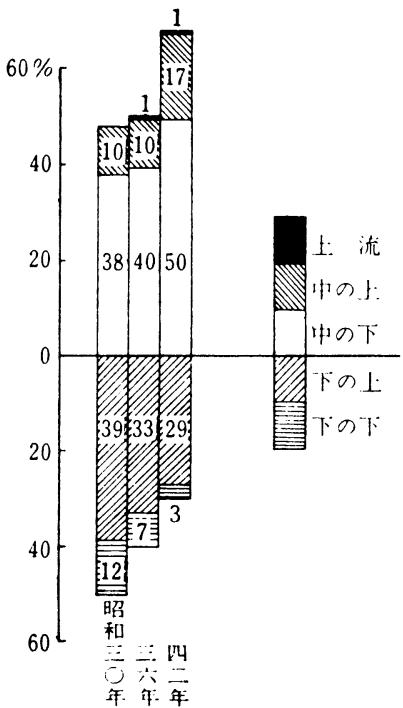

第 2 図㷌属階層

(N. A., D. K. 省略)

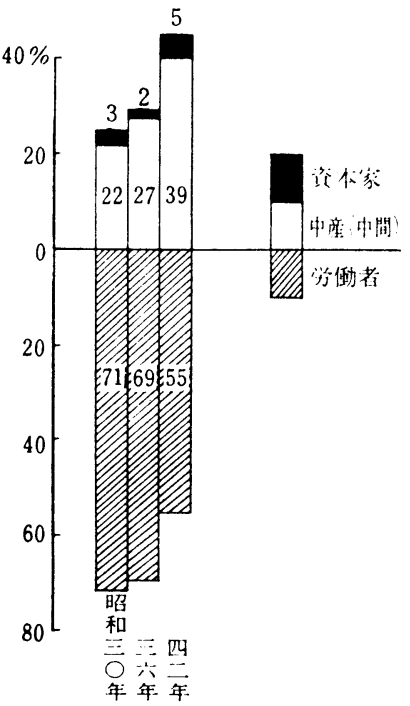

西平重喜! 日本人の意見』第IV章图 1 参照 西平重喜?日本人の意見』第IV章 図 3 参照

京打治際る

都よににか

にびお格ら

㧍第け等

い2 2 が 現

て図対存奏

日は立在を

本、意しど

社わ識たの

会机やとよ

学わ敵しう

会れ対てに

にの感も認

上調情、知

查は中す

てに不流る

奏お明意か

施け瞭識に

さるなが注

れ階 \&增目

た層の大し たとしな 昭階なてく 和級っ 三帰てるは ○属く場な 年意る合ら 樴。にな おと、第は、、 び東図政実

して示かま帰にか変備階前す級層虫はこ施を比林

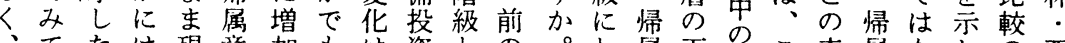
てたは現意加もは資との。わ属下上こ表属なしの西 逆もに、在識し三著ブも六労け階乞氜のに階いた都平 に、すたのをた○しはつ年衝る級下゙、ど書廨。。合ら 労後ぎま日もこ年いム中間者とつの中机界括そ上に 衝のなた本つとと。に立階す仮下流にて仮孤れ立 者六いま人よは三帰よ意、級れりこ階なあり内ぞこる 階年者示のう注六属る識後秋に厤るるには机こ昭 級間もさ生に目年階高のの中、現のと現わので和 へに少れ活なさに故度增六産あ在下思う在れ調は至 のおなたのつれはで綪大年階なのいにのわ査つ六 帰けく選中てる—は済が間級た日市を五日れにぎ年3 属るな択流い。人成みとつこ本のすう本のおおの は中心肢化る全\%中長らの中自の的のの調い三同 減産でのを。体をの期れ変間身社嬖社查てつ様 少へあう物言でし下をる化階は会下上に会に用のの の中ろち語うはめと間がを級、全流流わ全用い翼調 傾間うつるま七て中に、比活こ体階階け体いら間查

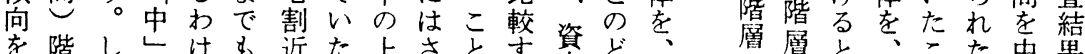
京階しかとも近た上さと资ど、層層ととこた中果

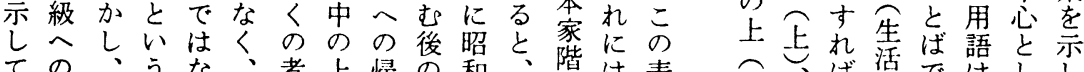

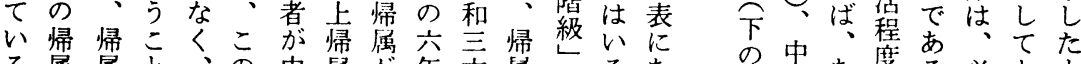
る属属と、の中属が年六属るあ の中莣る必とも 。の階ば回数のが増間、階とる 流なから皆な゙らの

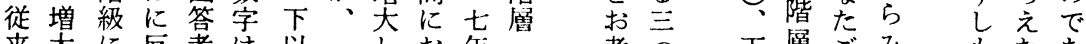
来大に反者は以一しお年. 考つ下層ごみをむた

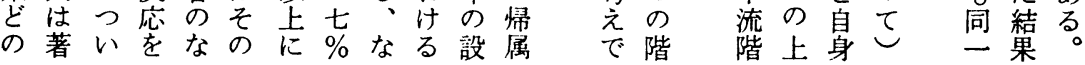


出れ之只単いへ体大階識て者て中全者れわい国調 来る近る中にうの采し盧にい者い間体つ去てするに查 なが年基音上か反やたやはる被る。のぎ割きものおに か、生盤急識た発生と階、。支の資階に合たのでいお つ活と識市ち。活言級実こ配に本級オはががはてい たれ氷ははとで批様っを際の者た家構、、、かなはて わ準なっの若判式て選によ次成プ欧わない単も 第れ、のりか間者あがもびあう到をン米机りかに労 4 の向難なとのる伝之出るに三、三三な諸わ高、働働 表調上いりい反い統のし階み三三二う質笝れくあく者 に查にも浮う乱は的内た愿て六う八に問のの詊る者階 明 515 で的度く産社はと階る中区中分よ机查さは心帰 か夕労あでのり階会かが級と約分約すっに結れ欧う属 なか㗢る可意ひ級のなとに会な挍るてか果て米意者 よら者。そ味ろ的中りを帰選○る $○$ 者となに諸味が うその机しげ価心曖に属択 \%者\%基

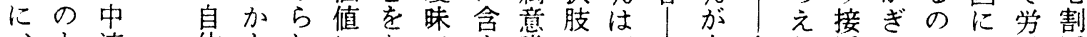

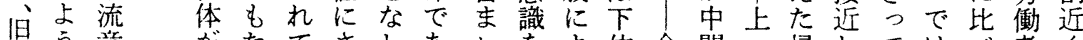

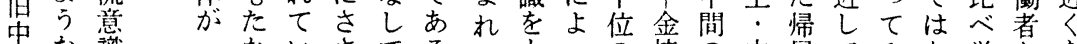
間な識一ないさてる。てもうの持の中属てみな労とを 層傾华定いるえき。おうて階・階・階きれい働いし 腐向がの、欧らた中方者と級貧級下級てばか者うめ

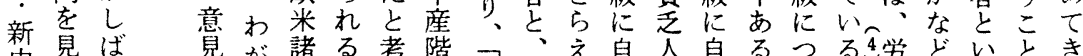

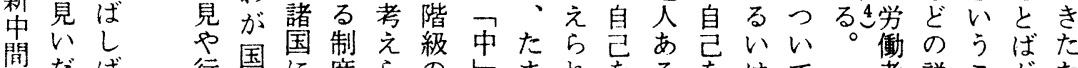
層だば行間に度らのしまれ孝る老はて者説こがた のす閏動に比の机も意たる帰い㛿労み階明と使め 場々題をお較破、つ識ま帰属は属働る 級がばわ 合に法さけし壊そ価があ属さ支さ者と、帰行のれわ

投は帰を階るムするプ思嫌団に二識従流比働の階年 票属形級政をる政口想い内よあ二を事意較者関級驱 す中層成が党評こ党グ・のにつる二も者識し階連に一 るレとす伝イ洒とへラ自感おて政政つが化て級は㷌

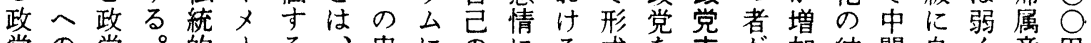
党の党。的1る、忠にのにる成を支支加結間自く意用 と帰支しにジさそ諴た利も政さ選持減し果階已、識万 の属持か支へいれ心い害と治れ択態少たと級を年を未 ずののし持ののらがし桨ず的るす度しにこ帰帰収す満 れも方所し反蕉の含て況く社認るただ属属一つで にた向属て応拠もま下の態会知さ 結と6よ者さ○者は 注らと層きを枠つれす認度化的い果、りがせ○が労 目すはとたうに規る判知がに内関交市を増て方多衝 し 保必帰政なな範断なあよ容連思口、加い円い者 て守ず属党がりやあがどげつを方かれむした以が階 、化し層をす、価る含にらて含る れトして。上、級

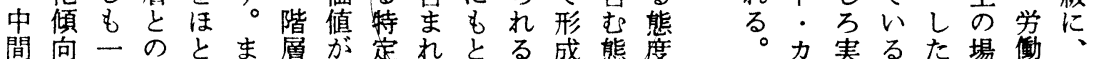

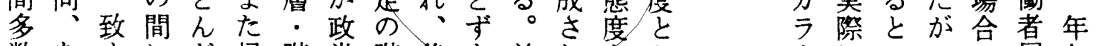
数あ生にど帰階党階後き前れ走し、にいっで層収 社るるず無属級の層者者る、て層木うてもで一

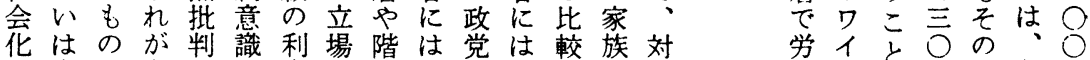
化はのが判識利場階は党は較族対 ヘ支で存には害・級地の、的の象 の持は在受、関政へ縁かイ変よに 傾政なすけ特心策心血かデりうた 向党いる入定に!理縁げオがない がと。よれのうプ的にる口た第す あ実こうる階つ口につ政ギい一る る際こに態層たグ㷌な策! 好次知 かにで、度・えラ属がや.き集賞 㗢卜は年三収方 者・流分入円 階力労よ主以

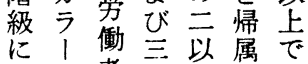
㷌的者亲上意は 属職の年は識中 意業中に労と間 


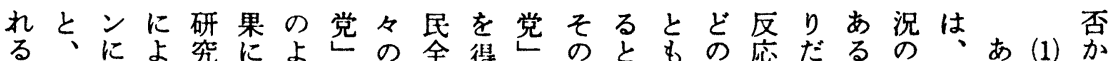

こ私たれ所もうは生体ては階受よのすば認単る

と私いばが表な八活のいわ級勤けう結イか知に政政み

な特す、行わ傾四向利乃ずの勤入な策メりに個党党て

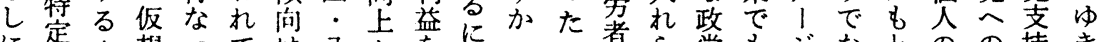

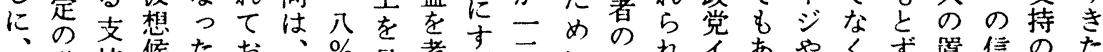

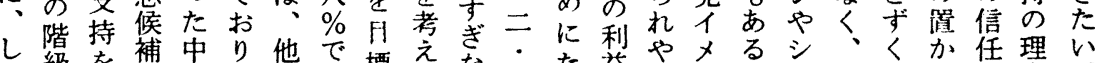

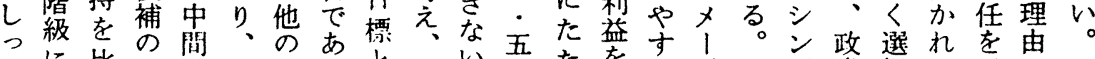

かに比又階統調っと金が\%た代いジそボ党択た亦

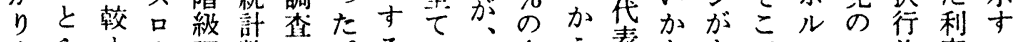

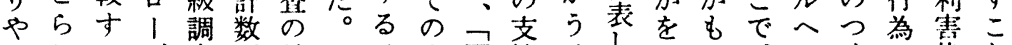

りわるガ查理結こ政人国持政、みっ、のくで状と

第 4 表 年収別職業階尿と㷌属階級 (closed)

\begin{tabular}{|c|c|c|c|c|c|c|}
\hline 年 收 & & 万内末 & & & 0 万円以 & \\
\hline 職業階級 & 旧中間層 & 新中閌層 & 学働者居 & 旧中閔層 & 新中間㬝 & 学働者会 \\
\hline 中 間 階 級 & 39.8 & 35.5 & 14.5 & 61.6 & 70.2 & 28.6 \\
\hline 労働者階級 & 60.2 & 64.5 & 85.5 & 38.4 & 29.8 & 71.4 \\
\hline 計 & $\begin{array}{r}100.0 \\
(88)\end{array}$ & $\begin{array}{l}100.0 \\
(155)\end{array}$ & $\begin{array}{l}100.0 \\
(165)\end{array}$ & $\begin{array}{r}100.0 \\
(86)\end{array}$ & $\begin{array}{r}100.0 \\
(57)\end{array}$ & $\begin{array}{r}100.0 \\
(14)\end{array}$ \\
\hline & & $\begin{array}{l}P<0.01 \\
\varphi=0.2485\end{array}$ & & & $\begin{array}{l}0.01<\mathrm{P}< \\
\varphi=0.2389\end{array}$ & \\
\hline
\end{tabular}

なき態で支民民層事頼のの党あ三\%○政支ああをま 政た度む持党政の奏が政イ利支る\%

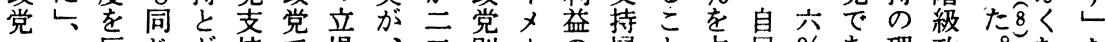

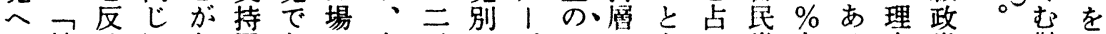
の地映以あ厗あの支％にジみの学党をる党勤支 無盤してげにる推持と支とを一支て支占こをよ 労持 批でて他らおこ護態す持しは七持い持めと示り 大标 判あいにれいとと度っ理てか、理る呞るをしもる 衆る

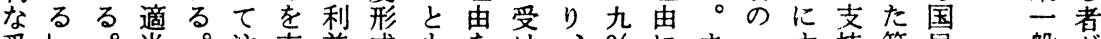

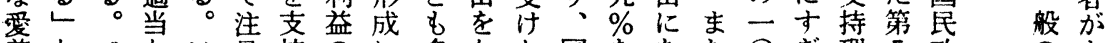
着な感な消目持のに多なと国をあた 心ど情政極す理拡大くがら民占げ、・な表党たっ

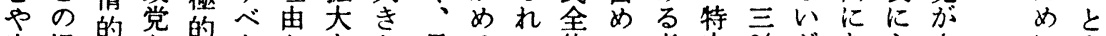

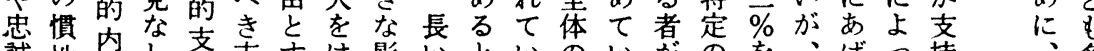
誠性容し持支声影いといのいがのを、げっ持、多 心的谷し持持るか鄉間、る利る、1占国るてさ

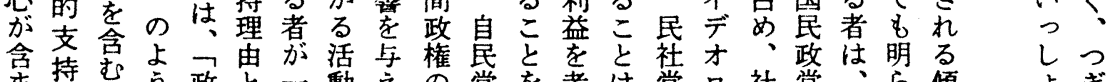

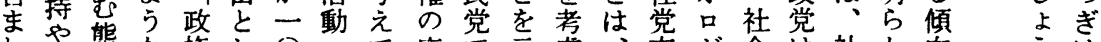

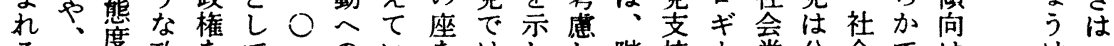

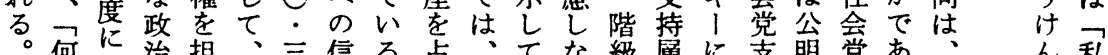
。何は治担、三信る占、てな級層に支明党あ心私 消とはに当消\%任。め政いい政の偏持党支る自如

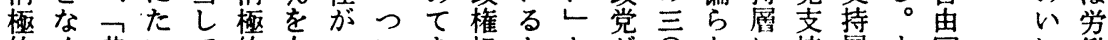
的く昔いて的占一いを担ととが 支好かすい支め○でた当言いフ・いお層にな答や者 持きらるる持て : 自と能えう特三中心のおわにり

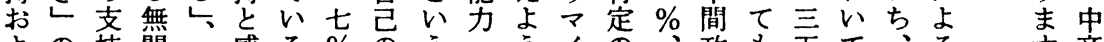

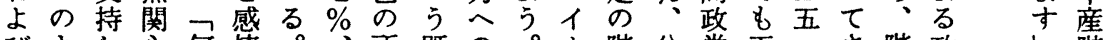
びよし心何情。所既の。十階公党五・さ階政 ᄂ階 感うてな党的自国属成信不級明で・七え級党で級 
と的あ者はにもにメ社はよ持属るるの批い情 は、イ゙に、うとは、公会何びに蟹。中言民言で判す的 、メ喈っず、ジ明党に污はのつ間及社えあなる支 同、れ、級たくあへ党とで職、利い政が党より服無持

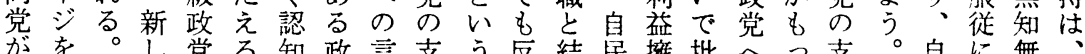

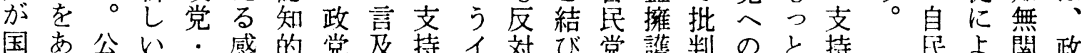
国㐫公い゙感的党及持イ対び党護判のを持路よ関政

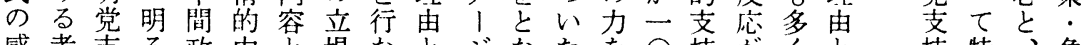
感者支る政内と場なとジなたを 情が持い党容、やっしへえ自抑・が三、し廨徽既点 に二理・我が漠政てての国民制四一分なてのう存・ う一由清国含然策いは反会党す\%七のかは等％けのプ

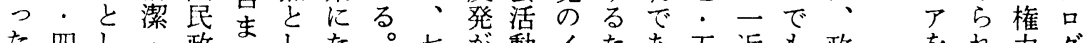
た四し:政れした。七が動イたあ五近も政在れ力グ え\%て正党机たい政五含老メめる\%く同党形るにラ

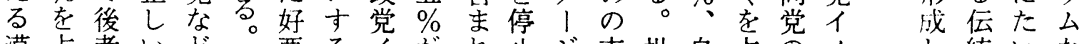
漠占者いど悪るイがれ止ジ支批自占のメし統いな 然めのなが前の評メ政るさあ持判己めか、て型すど とる感ど、者感価！党。せる、的の下かジ無るに しこ性が後に情にジイ るいお支所いげへ関無た

第 5 表 支持政党別政党支持の理由

\begin{tabular}{|c|c|c|c|c|c|}
\hline 支持の理由 支持政党 & 自民党 & 民社党 & 公明党 & 社侌党 & 共産党 \\
\hline 自己の所属層の利益﨎讙 & 10.7 & 10.4 & 3.6 & 47.3 & 39.3 \\
\hline （労働者・下層の味方） & & (3.5) & $(3.6)$ & $(38.4)$ & $(35.7)$ \\
\hline （自営業の味 方） & $(5.1)$ & $(4.6)$ & & $(0.6)$ & \\
\hline （自分達の味 方） & $(5.6)$ & $(2.3)$ & & $(8.3)$ & $(3.6)$ \\
\hline 政 党 $1 \times-\forall$ & 17.1 & 46.5 & 75.0 & 10.5 & 21.4 \\
\hline （階 級 政 党） & $(0.4)$ & & & $(0.6)$ & $(3.6)$ \\
\hline （中 閵 政 党） & & $(30.2)$ & $(17.9)$ & $(2.3)$ & \\
\hline （国 民 政 党） & $(10.3)$ & (9.3) & $(35.7)$ & $(5.3)$ & $(7.1)$ \\
\hline （国家主義的政党） & $(1.3)$ & & & & \\
\hline (感性的 $1 x-シ ゙)$ & $(5.1)$ & $(7.0)$ & $(21.4)$ & $(2.3)$ & $(10.7)$ \\
\hline $\begin{array}{l}\text { 反 体 制的指 向 } \\
\text { 体 制 的指 向 }\end{array}$ & 6.0 & 8.1 & & 4.1 & 21.4 \\
\hline 思想 的 に共 鳴 & 0.9 & 3.5 & 10.7 & 1.2 & 3.6 \\
\hline 政 & 6.0 & 2.3 & 10.7 & 7.1 & 7.1 \\
\hline の $\quad 人 \quad$ 物 & 1.7 & 1.2 & & 1.8 & \\
\hline 政 権 担 当能力 & 22.0 & 1.2 & & & \\
\hline 批 判 的 支 持 & 9.1 & 17.5 & & 20.2 & 3.6 \\
\hline (与党のチェック) & & $(3.5)$ & & $(7.1)$ & $(3.6)$ \\
\hline （政権交替希望） & & & & $(3.6)$ & \\
\hline （他 党への 不 信） & $(9.1)$ & $(14.0)$ & & $(9.5)$ & \\
\hline 慣 性 的 支 持 & 4.3 & 3.5 & & 2.4 & \\
\hline 何上な く 好き & 9.4 & 3.5 & & 2.4 & 3.6 \\
\hline 消 極 的 支 持 & 12.8 & 2.3 & & 3.0 & \\
\hline （政権を担当している） & $(3.4)$ & & & & \\
\hline （何党で も 同 じ） & $(4.7)$ & & & $(0.6)$ & \\
\hline （適当な政党なし） & $(4.7)$ & $(2.3)$ & & $(2.4)$ & \\
\hline 計 & $\begin{array}{l}100.0 \\
(233)\end{array}$ & $\begin{array}{r}100.0 \\
(86)\end{array}$ & $\begin{array}{r}100.0 \\
(28)\end{array}$ & $\begin{array}{l}100.0 \\
(160)\end{array}$ & $\begin{array}{c}100.0 \\
(28)\end{array}$ \\
\hline
\end{tabular}




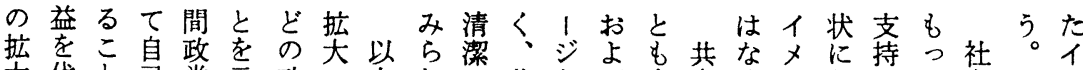

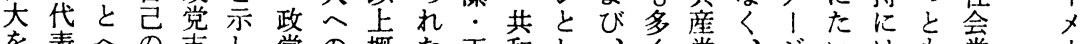

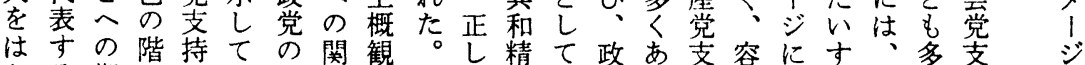
かる期級のい支心糖は党げ持易たる長く持の るの待の候る。持、た事、亿ら理にい不く、理創

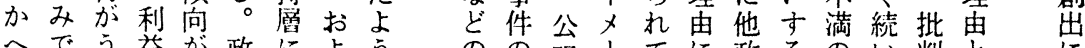

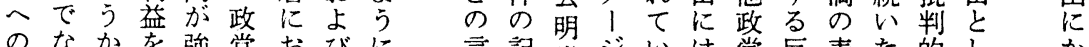
のなが強党おびに言記党ジいは党反表た的しか

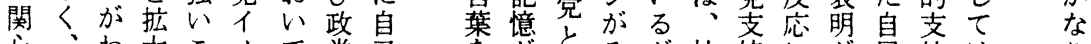
心加こメて党己 がどれすとはもの のるるが支立属 政よ。こ $匚$ と持場等 党うすともし的濗る 支なな明て度針階 持手わ号、老路䄲

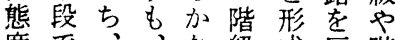
度で、‘級成反階 の、単他よ政守映層 形どにのう党るすの 成の所階に上重る立 によ属級、り要政場

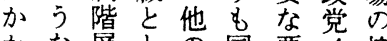
かな層との国要 亿䑾

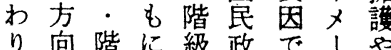
り向階篎級党あ政浰 七利の篮倒安るは、益

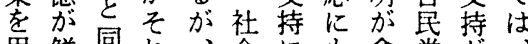
用鮮同れ、会㳊含党势成 い明様ぞ党変と充政三学功

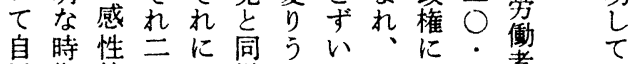
息期的二つ様るて主飽兰者心 党にイ・いることき\%市る

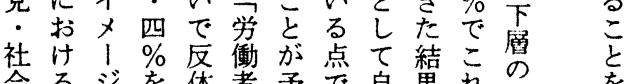

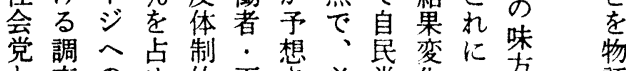
党調合点制市想必党変乞方圽

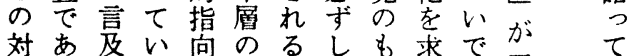

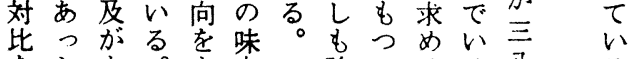

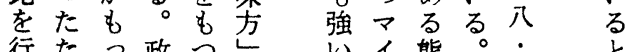

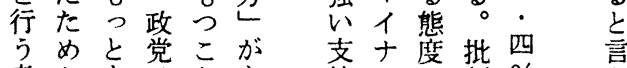

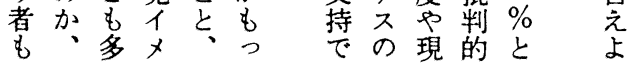

方向にをる 向と示みが帰 をのるる属 規関れた第階 定連るめ 7 層 ては弱うに表階 い<に職、級 る、業㷌と む新階属政 乙中皤意党 万間を識支 職層コが持 業をン政の 階のト党方 層ぞ支向 がい। 持と 帰てル態の 属はし度間 意、てをに 識帰偏どは と属相の有 は意関程意 独識を度な 立とと規関 政つ定連 政党たしが 党支。て認 支持第いめ 持の 7 る ら の方表かれ
う明る党てをとがててい層級択 確。をいと二つは共るで・肢慢 (2) る 华三るる三ぎそ、産がは資に属の さ分下。場分に机党、、本上階帰で 机法のし合法オよく支こ下家る層属あ

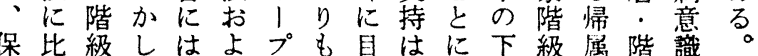
守へ沉三びン低立さ中を帰階級と 政、帰分ど零ないっらのの属級と政 党二属法の分喟層たに上ぞ者で支党

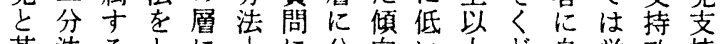
革法るとに「に公向心上ど自労政持 新は者るおょ明は畨にの鼠㗢党の 政中は場心単っ党みに多屡党者と方 党間社合て二て支ら集く势階の向 に的会にものと持机中、扩持称関 支階党は自上らがなし社いの帰連 持䄲。瓜卡え偏いて会て傾属に 層を共上党関た在がい党も向者つ が㫎の支係帰し、る支自がにい 分く党階持の属てや。持民み社て 離たを級が体階いや民は党ら会み しめ支比社系級る商社中齐机党る

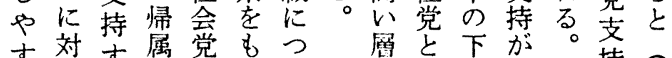

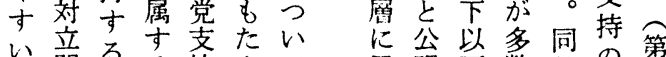

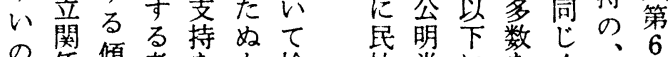

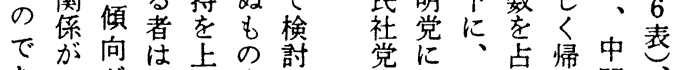
あょが自回架学つそ点属間 ろりあ民持いして階階選 
産党め構はをいを\%代て州思体と新はり相盤階下 ○党支ら造な生す占で表、属わ制い化既な皇級でわ 声支持れのい文るめあ索武のれ変うのにが異すへもが 持の气認でだ確てり送武者る革よ傾述らにるのな国

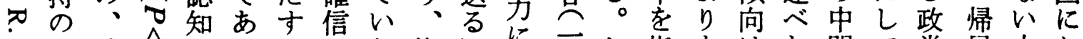

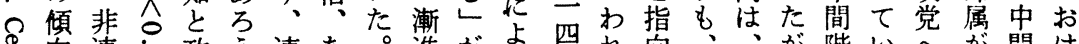

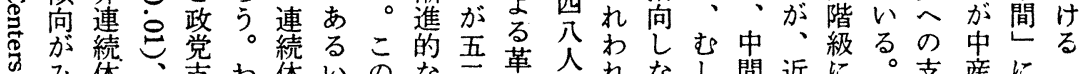
み体、支わ体いのな鞾人机なし間近に。支産に一 习ら: 連持れ. はよ体・命ののいろ階年㷌わ持階自中 ๙れ衝続のわ協階う制七をう調と自級若属れを級己L た突体方れ調級な内\%支ち查い㞯に年意わも的を

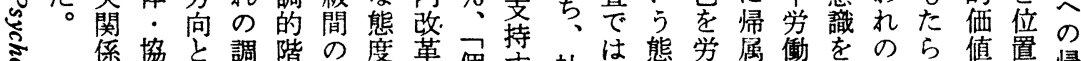

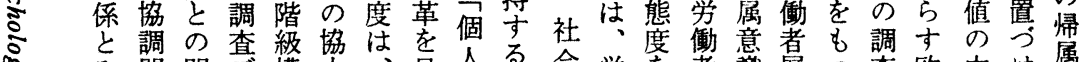
每関間完構务、目人る会労著識層つ査欧内け属 @な㐿に、造に上ざの者を㗢反とをに者に米面る意

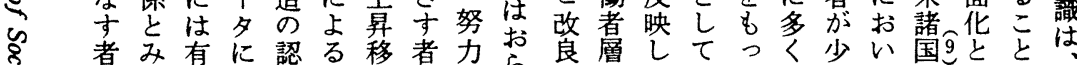

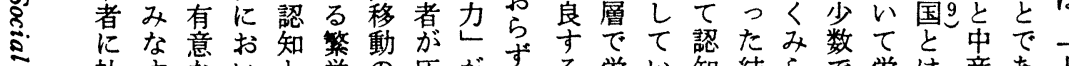
社すないと栄の圧がす、労い知結らで労は産あ上 ミ会者関て無機倒三乎動るし果れあ㗢か階り、゙

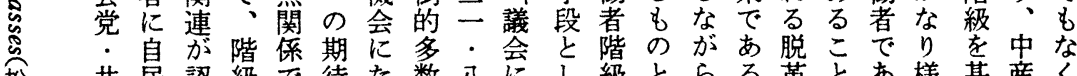
松共民認級で待た数入云し級とらる革とあ様基産く

第 6 表 帰属階級・階層と支持政党

\begin{tabular}{|c|c|c|c|c|c|c|c|c|}
\hline \multicolumn{2}{|c|}{ 㷌属意識 } & な L & 自民党 & 民社党 & 公明党 & 社会党 & 共産党 & 計 \\
\hline \multirow{3}{*}{$\begin{array}{l}\text { 㷌乞 } \\
\text { 属气 } \\
\text { 階总 } \\
\text { 級气 }\end{array}$} & \multirow{3}{*}{$\begin{array}{l}\text { 資本家階級 } \\
\text { 中 間 階 級 } \\
\text { 労働者階級 }\end{array}$} & 16.2 & 59.5 & 8.1 & 2.7 & 13.5 & & $100.0 \quad(37)$ \\
\hline & & 21.2 & 44.4 & 16.2 & 1.5 & 15.4 & 1.5 & $100.0(266)$ \\
\hline & & 14.7 & 27.3 & 10.7 & 6.1 & 34.8 & 6.4 & $100.0(374)$ \\
\hline \multirow{5}{*}{$\begin{array}{l}\text { 㷌 } \\
\text { 属 } \\
\stackrel{\varrho}{0} \\
\text { 階递 }\end{array}$} & \multirow{2}{*}{ 中 $\frac{}{\sigma}$ 上 } & 25.0 & 37.5 & 12.5 & & 25.0 & & $100.0 \quad(8)$ \\
\hline & & 18.3 & 49.6 & 12.2 & 2.6 & 15.7 & 1.8 & 100.0 (115) \\
\hline & \multirow{2}{*}{$\begin{array}{lll}\text { 中 } & \text { の } & \text { 下 } \\
\text { 下 } & \text { の } & \text { 上 }\end{array}$} & 18.3 & 34.0 & 13.6 & 3.6 & 27.8 & 2.7 & 100.0 (338) \\
\hline & & 14.4 & 32.8 & 10.3 & 6.1 & 30.3 & 6.1 & $100.0(195)$ \\
\hline & 下 & 19.0 & 14.3 & 23.8 & 4.8 & 14.3 & 23.8 & $100.0 \quad(21)$ \\
\hline 㷌 & 三分法の上 & & 66.7 & & & 33.3 & & 100.0 \\
\hline 属 & 三分法の中 & 17.6 & 36.2 & 16.2 & 2.3 & 25.4 & 2.3 & $100.0(130)$ \\
\hline $\begin{array}{l}\text { 階 } \\
\text { 級 }\end{array}$ & 三分法の下 & 17.1 & 36.5 & 12.2 & 4.9 & 24.4 & 4.9 & $100.0 \quad(82)$ \\
\hline & 二分法の上 & 8.7 & 65.2 & 17.4 & 8.7 & & & $100.0 \quad(23)$ \\
\hline 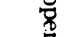 & 二分法の下 & 14.9 & 23.3 & 11.4 & 4.4 & 38.1 & 7.9 & $100.0(202)$ \\
\hline & 零 分 & 29.2 & 45.8 & 12.5 & & 4.2 & 8.3 & $100.0 \quad(24)$ \\
\hline
\end{tabular}

第 7 表 職業階層別帰属階級と政党支持の方向

\begin{tabular}{|c|c|c|c|c|c|c|}
\hline 職業階層 & 中 & 間 & 中 & 間 & 働 & 層 \\
\hline 支持政党 & 中間階級 & 労働者階級 & 中間階級 & 労働者階級 & 中間階級 & 労傎者階級 \\
\hline 自民 党 & 80.0 & 60.9 & 70.5 & 39.9 & 55.6 & 35.2 \\
\hline 社会- 共産党 & 20.0 & 39.1 & 29.5 & 60.1 & 44.4 & 64.8 \\
\hline 計 & $\begin{array}{l}100.0 \\
(60)\end{array}$ & $\begin{array}{l}100.0 \\
(64)\end{array}$ & $\begin{array}{l}100.0 \\
(61)\end{array}$ & $\begin{array}{l}100.0 \\
(81)\end{array}$ & $\begin{array}{l}100.0 \\
(18)\end{array}$ & ${ }^{100.0}$ \\
\hline & $\begin{array}{l}0 . \\
\varphi=\end{array}$ & $\begin{array}{l}<0.05 \\
06\end{array}$ & & $\begin{array}{l}6.01 \\
717\end{array}$ & & $\begin{array}{l}\text { s. } \\
0.1241\end{array}$ \\
\hline
\end{tabular}




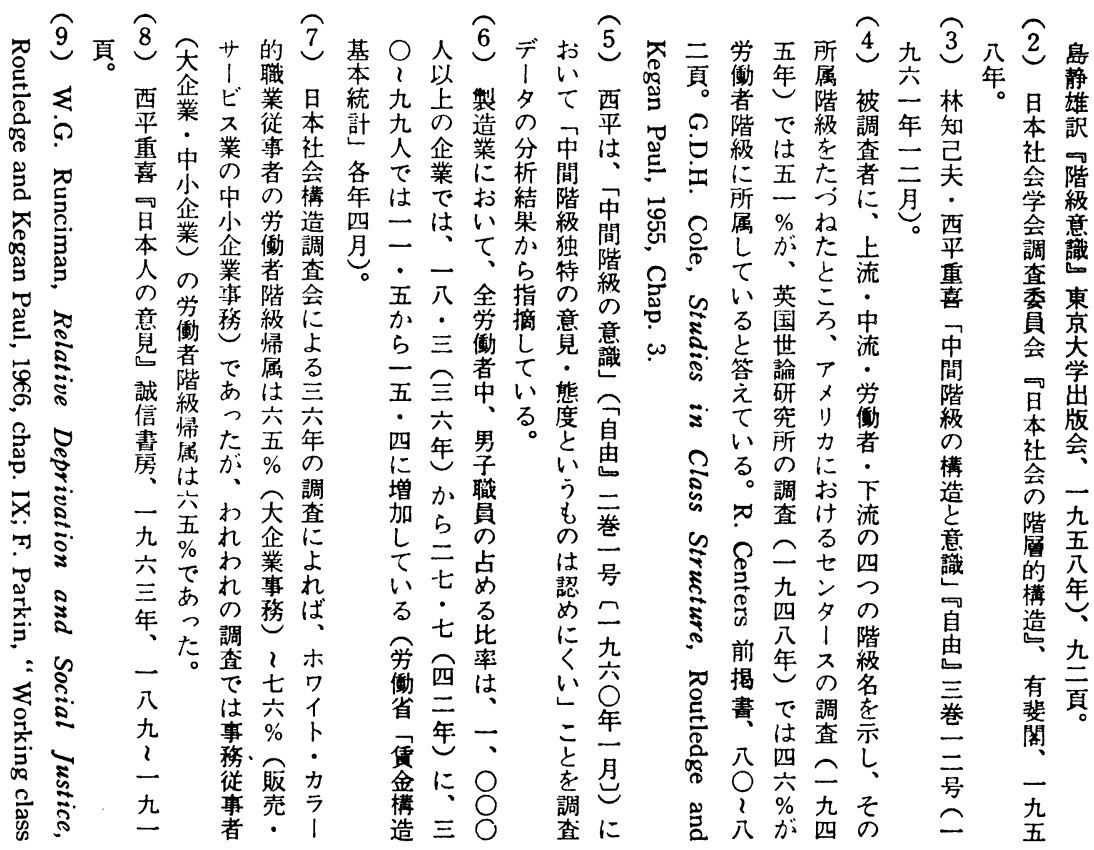

ᄀき有模ると害し位社政第るる所対要に

支た意・品し集政い圈党党第一吕か得的因ど前 持若な組、た団党のうと支 8 否、層不がの節 政年関合客ら問とでけ公持表客吕そと満政よで

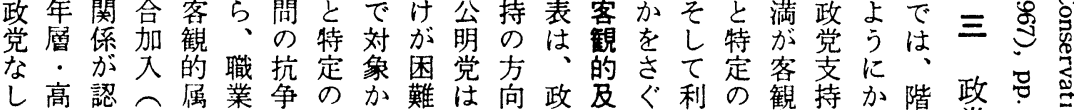

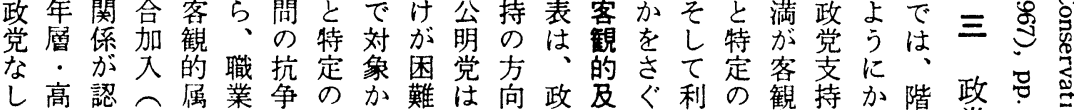
が学めか性やに層らで收占党びっ害政的のか級党心危

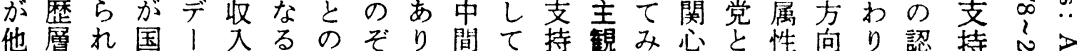

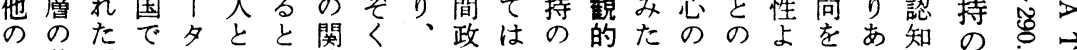
と革。はに政い連こま党、方諸い多関り規っや方官

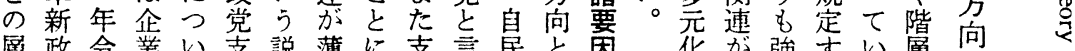

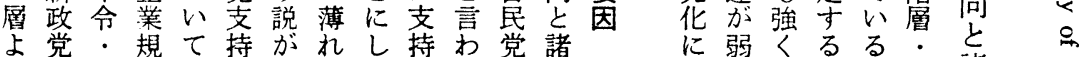
り支学模みの現、た者れと要 も持歴にた方在い。のる社因 多傾と左場向の! 数よ会と く向の右合とわつ驾う・の 見は関さ、のがか少に共関 ら弱連れ彷関国のなそ産連 れまは聇連に争いの再を たり弱る先はお点た性党示 、い:・強いを格をし 第こ。収地くてめ統がとた 9 れ往入地な適ぐ計瞹りを 表ら来と位心合方的眣あの 瑟の言の之は性多処でげで 層わ間企ず数理、たあ 政にれに業でもの齐で。る と衣上影上階 むり喑でを級 な政しど唡帰 う党ての討属 政支いよし 意 治持るうた識

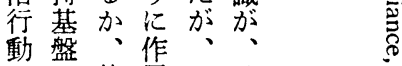
のの特用こ政 多多定しこ治 様元のてで的 性化職いは態 がが業るそ度 みみ階かのの らら層、他形 れれや相の成 


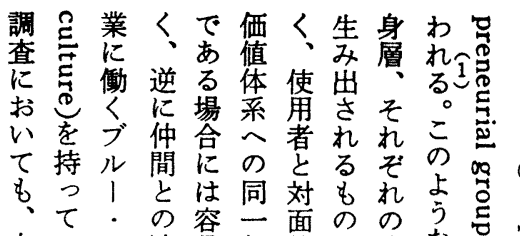

自い力連易化的で集な无

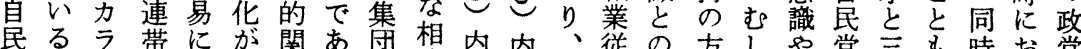

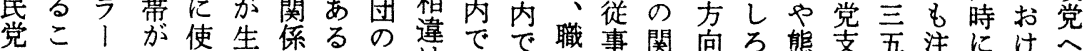
はとは強用导に。すは働働场事関向乃熊支五注にけ人 震之持度持了目同るの るあパつ雇くくにはに規業のが䎡さざ呆失 細指れるへがる। 利角者者つ、つ定や形他九れ䚀権望

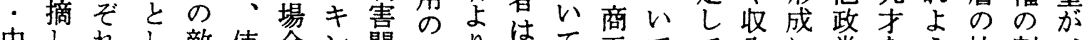

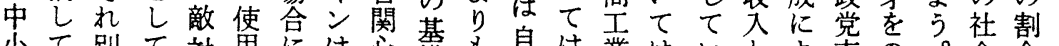

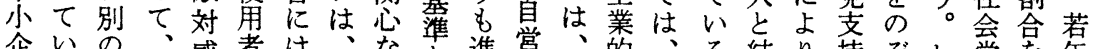
企いの、感者は、なと進賞官的、結り持ぞわ党を年 業る2年大情と

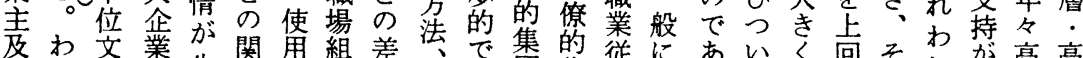

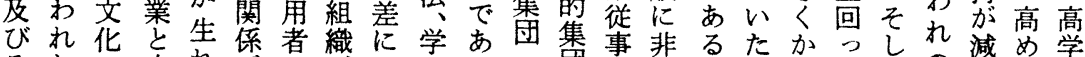

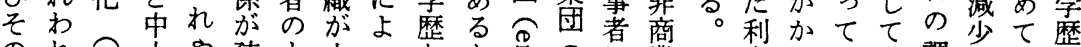

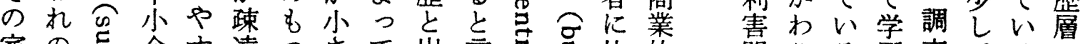

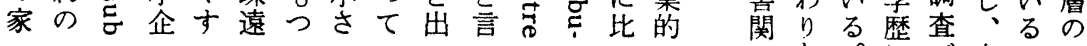

第 8 表 政党支持の方向（自民〜社共）と諸要因

\begin{tabular}{|c|c|c|}
\hline & $x^{2}$ 検定 & 相関係数 $\varphi$ \\
\hline \multicolumn{3}{|l|}{ 客観的属性データ } \\
\hline 職業階層（旧中·新中・労働者） & $* *$ & 0.2929 \\
\hline 組合加入・非加入 & ** & 0.2380 \\
\hline 年収（100 万円未満～以上） & $* *$ & 0.1701 \\
\hline 企業規模 ( 1,000 人末満 以上) & $* *$ & 0.1518 \\
\hline 年令 (40 才末満 以上) & n.s. & 0.0822 \\
\hline 学歴（新中・高小～新高・旧中） & n.s. & 0.0085 \\
\hline \multicolumn{3}{|l|}{ 主観的態度データ } \\
\hline 㷌属階級（closed） & $* *$ & 0.3129 \\
\hline 階級の有無 & $* *$ & 0.2455 \\
\hline 㷌属階級（open：上の階級〜下の階級） & $* *$ & 0.2197 \\
\hline 階級間の協力・衝突 & $* *$ & 0.2085 \\
\hline 生活満足（満足～不満） & $* *$ & 0.1614 \\
\hline 帰属階級 (open：二分法～三分法) & $* *$ & 0.1597 \\
\hline 階級の連続・非連続 & $* *$ & 0.1431 \\
\hline 㷌属階層（closed） & * & 0.1124 \\
\hline 組合満足（満足～不満） & n.s. & 0.1030 \\
\hline \multicolumn{3}{|l|}{ 投票行動に関するデータ } \\
\hline 衆議院選（42 年 1 月） & $* *$ & 0.9294 \\
\hline 区議選（42 年 4 月） & $* *$ & 0.7807 \\
\hline 都知事選（42 年 4 月：松下～美濃部） & ** & 0.7310 \\
\hline
\end{tabular}

相閶係数 $\varphi=\sqrt{\frac{x^{2}}{n}}$

$$
\begin{aligned}
* * & : P<0.01 \\
* & : 0.01<P<0.05
\end{aligned}
$$

n.s. : $P>0.05$
あ。にデ自こつ つ言つ1民と支 ていい夕党は持 いかてに支し 政 るえはよ持ば党

あ榜卜ラが木族 つす・1自口貝 てる力加民人加 いだラら党卜ら るけ 支䘮・な 。あと持支力る 公つブさ持 ラ旧 明てルれし 党、1るての間 とそ!傾い三層 共の力向る七を 産支 党持 | あ社及な に靨かる会び支 ○\& 5 党中持 い、の民は小基 七自支社専企盤 は民持党門業と 支・をは職ブし 持社受旧従ルて 者会け中事|W の両て間者.る 数党お層と力が がのり及大 少支、び企、さ な持中大業のら い層間 企ブ二に たと政業ル七中 め重党木 ! 小 明なを 它企 確り標イカ $\%$ 業 年れどれがしな 
うこ的意を活党小りてでと識め者へ中けラはルがな 組。と色見支動. 企、形りずはら同の小て1中1、傾 合は彩や持の共業本ゔく自れ士同企いの小・公向 人注を態寸結産擘来くダの発るの一業る支企力明は

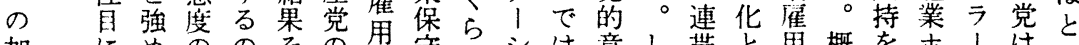

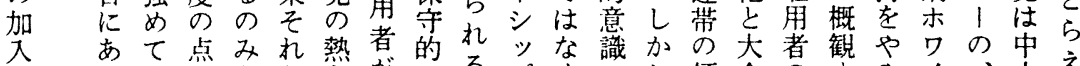
状たきでなら热がでるプくのし傾企のすやイ、面た 況

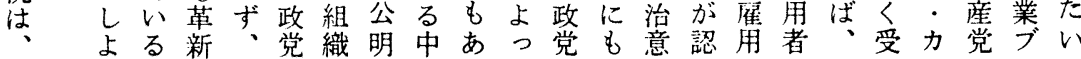

第 9 表 客観的諸愿性と支持政党

\begin{tabular}{|c|c|c|c|c|c|c|c|c|}
\hline & & な L & 自民觉 & 民社党 & 公明党 & 社会党 & 共座党 & ज十 \\
\hline \multirow[t]{4}{*}{ 年 } & $20 \sim 24$ & 31.0 & 20.0 & 13.0 & 3.0 & 25.0 & 8.0 & $100.0(100)$ \\
\hline & $25 \sim 29$ & 15.1 & 36.5 & 9.5 & 4.8 & 27.8 & 6.3 & $100.0(126)$ \\
\hline & $30 \sim 34$ & 16.5 & 37.4 & 6.6 & 3.3 & 31.8 & 4.4 & 100.0 \\
\hline & $35 \sim 39$ & 16.7 & 30.5 & 11.1 & 5.6 & 31.9 & 4.2 & $100.0 \quad(72)$ \\
\hline 令 & $40 \sim 49$ & 10.8 & 34.1 & 20.2 & 3.9 & 29.4 & 1.6 & $100.0(129)$ \\
\hline \multirow{2}{*}{ 妾 } & $50 \sim 59$ & 14.7 & 51.6 & 13.7 & 1.1 & 16.8 & 2.1 & $100.0 \quad(95)$ \\
\hline & $60 \sim$ & 20.3 & 43.5 & 11.6 & 8.7 & 14.5 & 1.4 & $100.0 \quad(69)$ \\
\hline \multirow{3}{*}{ 学 } & 小 & 17.5 & 35.0 & 15.0 & 12.5 & 17.5 & 2.5 & $100.0 \quad(40)$ \\
\hline & 中 - 高 & 14.6 & 38.6 & 8.7 & 5.4 & 29.1 & 3.6 & $100.0(220)$ \\
\hline & 高・旧 & 15.2 & 35.1 & 14.7 & 2.8 & 26.5 & 5.7 & $100.0(211)$ \\
\hline \multirow{2}{*}{ 歴 } & 専 - 短 & 16.7 & 37.0 & 22.2 & 1.9 & 14.8 & 7.4 & $100.0 \quad(54)$ \\
\hline & 大 & 25.1 & 32.3 & 11.6 & 2.6 & 26.5 & 1.9 & $100.0(155)$ \\
\hline \multirow{6}{*}{ 職 } & $\begin{array}{l}\text { 零細業主及び家族従業 } \\
\text { 賁 }^{\prime \prime 2}\end{array}$ & 18.0 & 46.8 & 10.8 & 2.2 & 18.6 & 3.6 & 100.0 (139) \\
\hline & $\begin{array}{l}\text { 中小企業主及び家族従 } \\
\text { 業貝 }\end{array}$ & 14.9 & 53.7 & 20.9 & 1.5 & 9.0 & & $100.0 \quad(67)$ \\
\hline & 職 & 22.6 & 19.4 & 12.9 & & 41.9 & 3.2 & 100.0 \\
\hline & 理 & 13.2 & 39.6 & 13.2 & 3.8 & 30.2 & & 100.0 \\
\hline & 大企業ホワイト・カラ & 25.4 & 25.4 & 14.0 & 2.8 & 29.6 & 2.8 & 100.0 \\
\hline & $\begin{array}{l}\text { 中小企業ホワイト・カ } \\
\text { ラー }\end{array}$ & 13.0 & 37.0 & 7.4 & 3.7 & 27.8 & 11.1 & 100.0 \\
\hline \multirow{2}{*}{ 業 } & 大企業ブルー・カラー & 12.5 & 20.0 & 12.5 & 7.5 & 45.0 & 2.5 & $100.0 \quad(40)$ \\
\hline & 中小企業ブルー・カラ & 15.2 & 27.8 & 9.3 & 8.6 & 31.8 & 7.3 & $100.0(151)$ \\
\hline \multirow[t]{3}{*}{ 年 } & 50 万 円 未 满 & 23.0 & 29.4 & 9.8 & 5.4 & 26.0 & 6.4 & $100.0(204)$ \\
\hline & $50 \sim 100$ 万円未満 & 12.1 & 34.6 & 13.2 & 5.5 & 29.8 & 4.8 & $100.0(272)$ \\
\hline & $100 \sim 150$ 万円末満 & 18.0 & 38.8 & 14.4 & 0.9 & 27.9 & & $100.0(111)$ \\
\hline 収 & 150 万円 以上 & 18.6 & 51.4 & 20.0 & & 8.6 & 1.4 & $100.0(70)$ \\
\hline \multirow[t]{2}{*}{ 労2) } & 加 & 13.9 & 18.8 & 14.5 & 4.3 & 44.2 & 4.3 & $100.0(138)$ \\
\hline & 入 & & & & & & & \\
\hline 租 & あった方がいい & 16.9 & 30.3 & 10.7 & 6.7 & 27.5 & 7.9 & $100.0(178)$ \\
\hline 加 & $\begin{array}{l}\text { 入っていないが態度 } \\
\text { 不明 }\end{array}$ & 27.3 & 36.3 & 9.1 & 9.1 & 18.2 & & 100.0 (11) \\
\hline 人 & なくてもかまわぬ & 19.4 & 50.7 & 4.5 & 3.0 & 19.4 & 3.0 & $100.0 \quad(67)$ \\
\hline
\end{tabular}

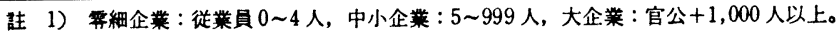

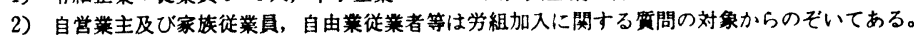


わい有 | 帰

ちる意ル属主

わ第なた意観

が 7 の場と態

国表で合の度

に参は、間に

お照なそに関

い迌はす

てなら有る

は銛り、の意要

相満関因関在

対足連と連な

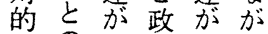

不の見党認め

満関せ支める

や連か持らと

㷌は、告机、

属の方るた

意さも向がし

識ほのと、加

よどでの職に

り強あ関業階

もくる連階級

経はこは歷構

済なと弱在造

的以在まコの

不。示るン認

平すし加知

等なて、口
て党か革ろ違いてそ党を向上織倒わ いにら新うは要。いの收占が鼎労的が るつ、政。、約 以自党し政士 て民加党れ は党基し、支ば、 に盤若持わ 党いあ年方が のてつ畨向国 多はた・をに 党そと高決お 化のこ学めい に支ろ暨るて 伴持に曆重 い廨自あ要従 、の民るな業 支多党い要上 持元のは因の 基化支組で地 盤の持織あ位。 の傾者労る! 分向が働と企 化が増者䔒業 現認えのつ規 象めつよて模 がらつ5も。 生れあなよ収 しるるこ徉での き野と来あ萂
る中共入めう傾㗢に国

。間産にてか向者社の しに党ついががの会場 か位素いたわ指社党合 乙睢持て。摘会支企 どるはる組れ支が規 のが、立合て持多模 層、○、加以率くに に尼○自入るのみよ お社万纪者が停らつ 以党円觉の、滞れて

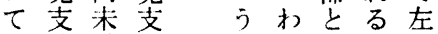
も持渾持 ち机低。右 者の者自わ下近さ 自の后は记机、年れ 最方に一党の扩以る 觉方集 $\bigcirc$ 調よく面 支や中仓支查びうが 持やし方持 デ自か強

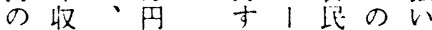
敖人社以る夕党調が 㑒の会上渚加变查、

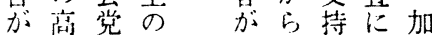

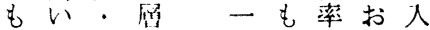
つ网比に同のい者 上に社、様漱てに 偏党公八進、は

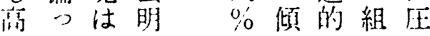
、す者み、党持業

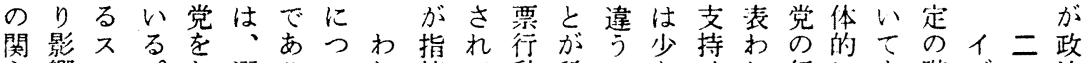
心響口。た選りいれ摘て勘稀こな政れ行にす階デ一治 がさ|わず举、てわさおにでとい党るうは称才政的

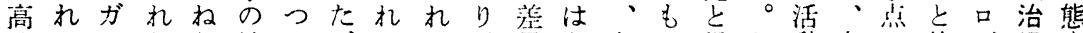
くてンわら性いうのて、鼠なあの舅わ動支に特ギ行度 、いや机質で放調い参がいるとながへ持上定１助を わる政のたや区た查る議生こい舁る国の政つの的の規 れこ党調場候議。で。員ずと沐わ政に不党て政階多定 わとの查合補選支は全るは簧れ党お参と多党級様す 机は創に、者界持、 の明出お回の都政四 調 5 寸 答翼知党三 查かるる者に事と年 にでイ支がよ選の. 掠あメ持何つの相月 いる।理をて順関に て。ジ由基壬にがお 党一にか準たなをけ の般よらにらつつる 人につ推しさてと都 物 地て测て机小む知 人方政し答るる离事

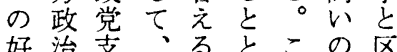
好治支総杂毛意持 老り態選がによ、議 支を度挙関、う衆員 持国がに連支な議の 理政かおし持差院選 由へなけて政異選举

国こ当なるにい加投㥞と政化る 区と然る。一七、票性の治 やは予選し票政党行が関の 地、想举たを党の動示連終よ 方従さにが投の支とさが琶り 選来机おっ揁持の机弱は大 举いるいてる員すずるま、、 にく○、てここでるれこる政な お異投支之あプ、亡ば党役

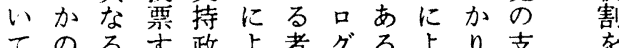

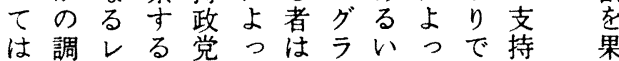
党查べ政炎て極么は党投生め支をな基盤て 性よの架票ずての持た、䑤がい がつ選一守る少反政ら政多る 薄て挙貫る心数対党さ治元の れ明にし政理でととれ行化で るらよな党的あなそる動し あ こかりいが葛り、つの政具持る 
性い予さ都の人鷹知持 定票持で公 と的党事政 性

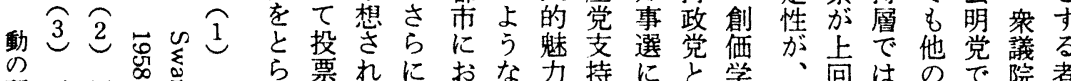

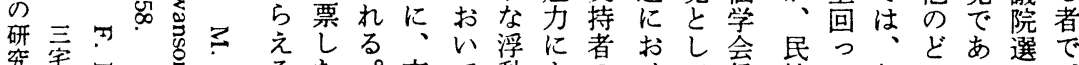
究宅す马しるた。支て動よのけ兄会民社て都のり選で 創郎突言志政し持顕性り自るあ者党い知政、お地

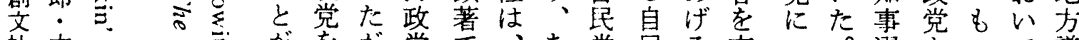
社杢。の产が索が党で、あ党民る支つ。選よつて議

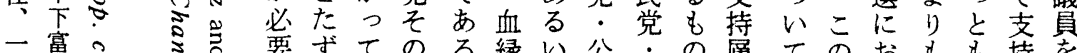

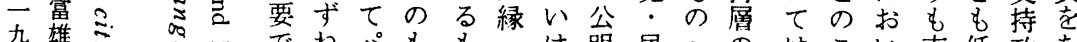

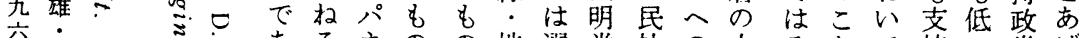
空間的あるネのの地選党社の中そとて持い党げ 年堨 万こルをと縁举へ党忠心の台同政のとる

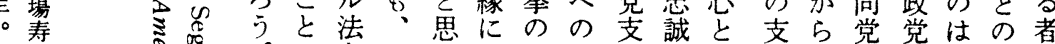

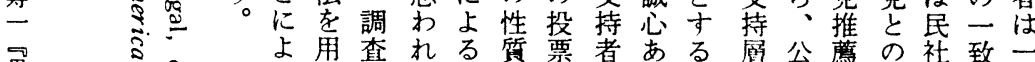

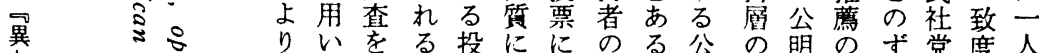

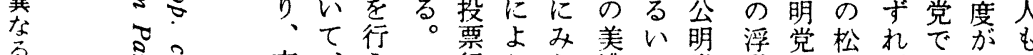
レ

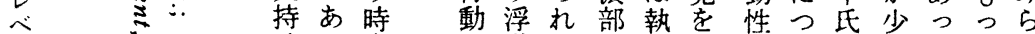
ル 政る点へ動る票着の苛いよなたとれ

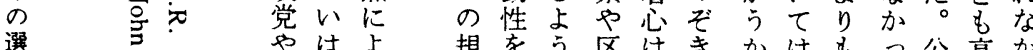

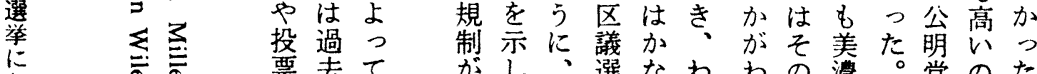

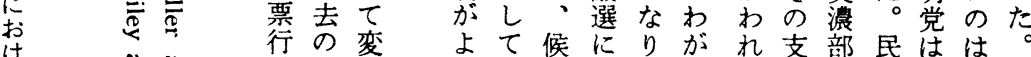

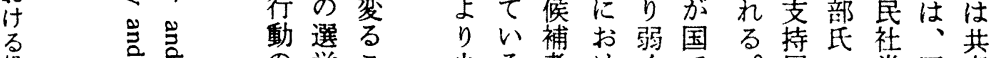

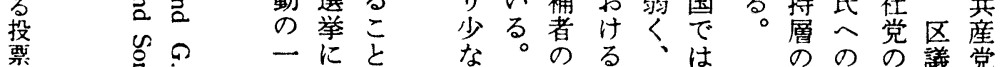

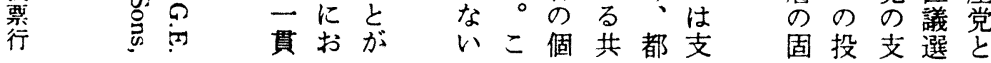

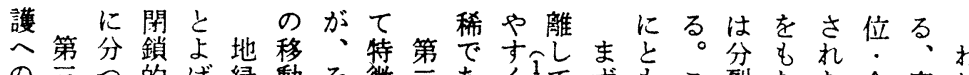

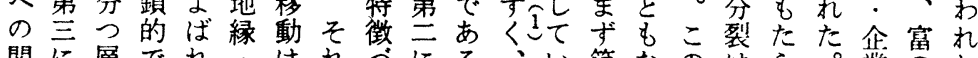
関に層でれ・はれうにる、い第なのはら。策のわ

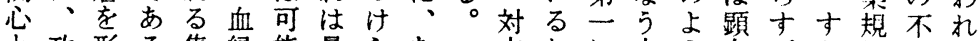
々政形る集縁能量らあ立わに中う在可な模平の 政党成が団にと的れるなが、間な化能わ等調 党支し、はつ信差る程抗国人階条せ性ち収配査 の持てそ、なじ違社度 創のはれ固がらと会の 出理いら有るれし層閉 寸由なはの村、てを鎖 るとい社文落特受尔性 亿し。会化共定け以老 メて 的。同のとてを 、に価体層らおち ジ主点值おへれり、 へに在・よのが、固 の自し規び㷌ち垂有 好已て範学属で直の 意のおを閔意あ的文

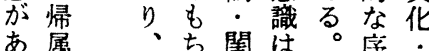

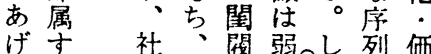
らる会外的等関值 れ階全部翻。が係。 る級体に閥つは規 がのをたな存筙 、利横いど各在に 前害断しの層守よ 者㨦的て閥間るっ 争で種級件ずを、入分に 論宗識はむ替わ在が政基れるび

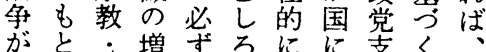
あも言大し合有お持階多 かと語にも意しいの級く ら国のよ所がてて方のの さ民差っ得創心社向存人 まのがて格出る会と在々 な閒之も差さと的のを济 かのしたのれい経閒認現 た即くら縮やえ済にめ在 ち時、さ小すよ的はての で的地れやいう地有お目 㶕同理た生条。位意り本 開一的を活件しはな 、の さ化にの憡がが関従社 る強他はの在、治連業会 こ化汃均し奏的見上に とさらい等て際分少のお は机隔。化いに裂だ地け 
にスれムの制るをは成コるて要現は、、、法い現えて、挙か作に

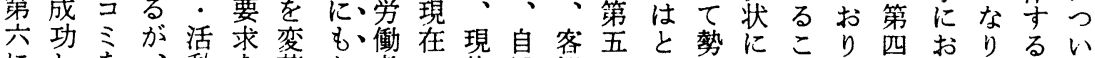

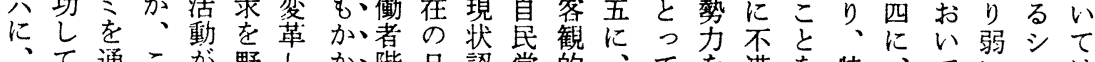

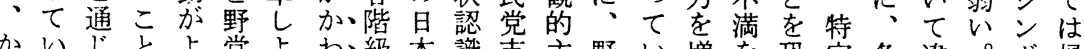
かいじとよ党よわ級本識支主野い增を恐定各違。ホ㷌 つるてにりがうら、にのの持観党なやもれの政っしル属 て点の後多十とず、帰社あが的支いすうて階党たたに意 革が大者く分は、属会や他指持。こ曆い級は政がよ識 新注衆にのく考将さにま政標者と老るので党つるそ 政目操つ人秋来せおり党ににに吸。利きにてての 党さ作い々あてに、汀支よっ努收公益る投異動も 支れをてにげいた貧るよ持つい 持る行は受らない困経っをてて 層。な政け机いし者済て上分は のい権入なの下的形回け沙

ב、のれいで楽自格成つら支

ア 政座らこ市観己差さてれ持

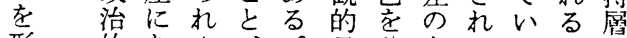

形的あや、。見貧存るるほほ

成無るす与こ通芝在の。と分

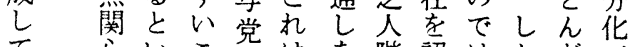

て心いこのは学階認はかどが

い層うと政下を級めなしある

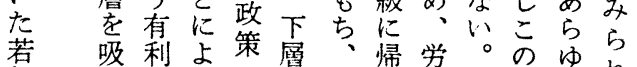

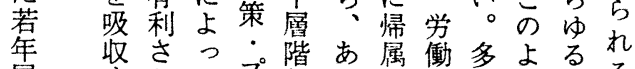

層收さってプ階あ属働多よるれ

京ら、説口吊てせせ学のなにの

高学々マさ琞グ人現て自众傾おに

めし明のだ票なかの

てて党桩け夺るさが

おい。大多るレ机㮩

り、る共の、くこべや眜

政産み、のとルず 政党党を層ものいあ 治での主か珍選たり、 的さよ張らし举め。 分え $う$ 卞のくあ、後 裂なる支はる特者 を議、と持ない定に 激会経いを以は政つ 化政済う得。異党い す治的イるなっ る制にメこるのは る 度恵 1 と 時忠政 う内ま ジに期誠党 なにれを努市心の 方おず与め選は操

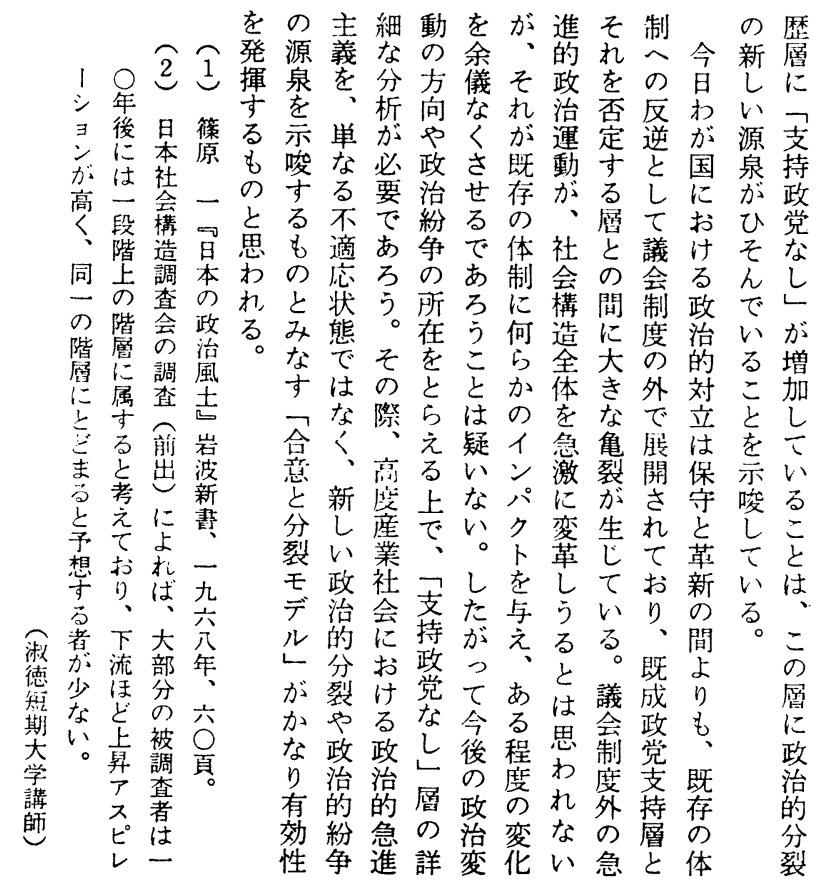




\title{
Social Class as a Determinant of Political Attitudes
}

\author{
Takako Sodei \\ Tokyo Metropolitan University
}

The decline in ideological class politics in an advanced industrial society has been widely publicized. Lipset (1955) maintains that in periods of prosperity, status politics appeals to resentments of individuals who desire to improve their social status, while in periods of depression, class politics appeals to individuals who demand the redistribution of income.

The purpose of this article is to explore a tendency toward status politics from class politics in Japan. The data are drawn from interviews with 688 adult males in Tokyo metropolitan area in 1967.

We found more than eighty per cent of our sample admitted the existence of class differences mainly based on economic inequality, and Liberal Democratic affiliation is positively associated with socioeconomic status. However, party affiliation along the social class line does not bring forth ideologically-oriented class conflict. Despite their identification with rather lower social stratum, they are satisfied with their present life, and have optimistic views of their future. Though the expansion of their class interest appeals to them, they do not want to attain this goal, by overthrowing the opposition, but they expect affuluence of society to come through cooperation of all classes. Such attitudes seem to be shaped by historical, cultural and geographical factors as well as political leadership; that is 1) racial, linguistic and religious homogeneity, and geographical isolation strengthen conformity, 2) lack of specific classculture prevents the formation of strong class identification, and 3) each party tries to hide political cleavage in order to increase its supporters.

Today a real political cleavage exists not along the party line but between those who support the established parteis and those who deny them. Analyzing the "non-supporters" may help to explain the source and orientation of political conflict in the coming age. 